\title{
Land management impacts on soil properties and initial soil erosion processes in olives and vegetable crops
}

\author{
Igor Bogunovic $^{1 *}$, Leon Josip Telak ${ }^{1}$, Paulo Pereira ${ }^{2}$, Vilim Filipovic ${ }^{1}$, Lana Filipovic ${ }^{1}$, \\ Aleksandra Percin ${ }^{1}$, Boris Durdevic ${ }^{3}$, Márta Birkás ${ }^{4}$, Igor Dekemati ${ }^{4}$, Jesus Rodrigo Comino ${ }^{5,6}$ \\ ${ }^{1}$ Faculty of Agriculture, University of Zagreb, Svetosimunska 25, HR-10000, Zagreb, Croatia. \\ 2 Environmental Management Laboratory, Mykolas Romeris University, LT-08303 Vilnius, Lithuania. \\ ${ }^{3}$ Faculty of Agrobiotechnical Sciences Osijek, Josip Juraj Strossmayer University of Osijek, Vladimira Preloga 1, HR-31000, Osijek, \\ Croatia. \\ ${ }^{4}$ Szent Istvan University, Faculty of Agricultural and Environmental Sciences, Gödöllö, Páter K. u. 1, H-2103, Gödöllö, Hungary. \\ ${ }^{5}$ Department of Physical Geography, University of Trier, Germany. \\ ${ }^{6}$ Soil Erosion and Degradation Research Group, Department of Geography, Valencia University, Blasco Ibàñez, 28, 46010 Valencia, Spain. \\ * Corresponding author. Tel.: +385-1-2393815. E-mail: ibogunovic@agr.hr
}

\begin{abstract}
This research aims to assess the impacts of soil use management on runoff, soil losses, and their main soil controls in vegetable cropland (CROP), tilled olives (OT), and grass-covered olive orchards (OGC) on Leptosol in Croatia. Soil analysis and rainfall simulation experiments were conducted to quantify runoff (Run), soil, and nutrient losses. Bulk density (BD) was significantly higher at OT plots, in addition to the CROP plots. Water-stable aggregates (WSA), mean weight diameter (MWD), and soil organic matter (OM) were significantly higher in OGC plots compared to the other land uses. Run and soil loss (SL) were significantly higher in CROP and OT plots compared to the OGC plots. The CROP plots showed soil management that can be considered as unsustainable with 52, 68- and 146-times higher losses of phosphorus (P loss), nitrogen ( $\mathrm{N}$ loss), and carbon ( $\mathrm{C}$ loss) compared to the OGC plots. The principal component analysis showed that MWD was associated with vegetation cover (VC), water-holding capacity (WHC), WSA, OM, total nitrogen (TN), time to ponding (TP), and time to runoff (TR). These variables were negatively related to $\mathrm{P}_{2} \mathrm{O}_{5}$, Run, $\mathrm{SL}$, and $\mathrm{P}, \mathrm{N}$, and $\mathrm{C}$ loss. Results indicate the need for the adoption of conservation strategies in croplands and olive orchards.
\end{abstract}

Keywords: Soil erosion; Tillage; Rainfall simulation; Agriculture land management; Mediterranean.

\section{INTRODUCTION}

Essential for life on the Earth, soils directly or indirectly sustaining $95 \%$ of the produced food over the world (FAO, 2015). Thus, the conservation of soils for natural ecosystems and human health is vital (Steffan et al., 2018). Along with functions such as supplying a medium for plants to take the nutrients, water, and support the roots, soils provide other necessary ecosystem services such as nutrient cycling, water quality regulation, water supply regulation, air quality regulation, climate regulation, and food, fiber, and fuel supply (Pereira et al., 2018a). Soils are also crucial for the stability and resilience of the Earth's surface environment (Ludwig et al., 2018). However, several soil functions are affected by land degradation processes, such as nutrient depletion and soil erosion (García-Ruiz et al., 2017). In order to feed an increasing human population and animals, agricultural soils are being affected by non-sustainable land management uses, which are characterized by an intensive production or the use of heavy machinery with negative impacts on soil nutrients and biodiversity (Ebabu et al., 2020; Sanaullah et al., 2020). Previous studies recognized a high variation in runoff (Run) and soil erosion by water due to land-use changes, wildfires, and grazing (Biddoccu et al., 2017; Dalla Rosa et al., 2017; Pereira et al., 2018b). However, along the Mediterranean area, millennia agricultural practices, vulnerable environment, extreme climate conditions characterized by extreme and irregular rainfall events, long dry periods on bare soils are recognized as drivers for higher soil and water losses (Covelli et al., 2020; Kosmas et al., 2015; Salvia et al., 2019).
In agricultural ecosystems, soil losses are high on bare lands. Several authors demonstrated that the intensive tillage practices such as plowing, rotatory-type tillage or herbicides application, increase soil losses above the tolerable levels (Abidela Hussein et al., 2019; Gómez et al., 2018; Ryken et al., 2018). Tillage and crop protection managements require a high number of machinery passes. This increases soil organic matter (OM) depletion (Ebabu et al., 2020), the occurrence of crust (Birkas et al., 2014), and soil compaction (Biddoccu et al., 2017), meanwhile the pore system is unfavorably modified, and infiltration is reduced (Novara et al., 2020). Therefore, land use and management are key factors controlling the intensity and the frequency of overland flow and soil loss (Baiamonte et al., 2019; Kosmas et al., 1997).

Olive orchards and vegetables are typical crops of traditional production spread in the rural areas of Mediterranean Croatia. Olive orchards are established mainly on sloped and low quality and productivity soils (Beaufoy and Pienkowski, 2000), while vegetables require higher labor inputs and intensive highproductivity agricultural practices (Ebert et al., 2019). Therefore, each land use has a high susceptibility to soil degradation if no correct land management plans are designed and applied.

In the Mediterranean, several works indicate that soil erosion is the major problem associated with olive orchards (e.g., Gómez et al., 2018; Martínez et al., 2006; Taguas et al., 2015). Naturally, reported soil losses much depend on scale and methodology, as is previously highlighted (Fleskens and Stroosnijder, 2007; Gómez et al., 2008). Nevertheless, soil disturbance and bare soil in olive orchards produce soil loss 
more than $25 \mathrm{t} \mathrm{ha}^{-1}$ year $^{-1}$ if rills and gullies occur (Taguas et al., 2015). However, other research even demonstrated increased erosion rates of $47 \mathrm{tha}^{-1}$ year $^{-1}$ (Vanwalleghem et al., 2011). In cropland vegetable fields, soils also exceed very often tolerable soil loss (Montgomery, 2007), reaching $12 \mathrm{t} \mathrm{ha}^{-1}$ year $^{-1}$ (Bagarello et al., 2018; O'Rourke and Petersen, 2016; Pournader et al., 2018; Preiti et al., 2017). In this context, the preservation management strategies developed in the shape of no-tillage (croplands), grass cover (orchards), or mulching (croplands and orchards) (Triplett and Dick, 2008) are key to conserve the soils. Such practices decrease sediment, nutrient and water losses for several magnitudes in addition to conventional tillage (Bogunovic et al., 2018; Gómez et al., 2009; Kosmas et al., 1997).

Despite the generally high erosion rates in olive orchards and in areas where vegetable production is dominant, the majority of cropland cultivation in the Mediterranean area is still under unsustainable management, as is the case for Croatia and no updated information with in situ measurements exists for Croatia (Bogunovic et al., 2020). Several scientists studied different land management impacts on specific soil properties and hydrological responses during the last two decades. However, combining different point of views such as in situ experiments, conservative and traditional land uses such as olives and vegetables and their respective response to the activation of the initial soil erosion processes is missing (e.g., Arhonditsis et al., 2000; Blavet et al., 2009; Dunjó et al., 2004; Gilley et al., 1997; Mohammad and Adam, 2010; Návar and Synnott, 2000; Qiang et al., 2016). This work aims to compare the impact of different land management on soil properties and hydrological response in olive orchards and vegetable croplands. To achieve this goal, soil analysis, and rainfall simulation experiments were used for the first time in Dalmatia, Croatia.

\section{MATERIALS AND METHODS \\ Study area}

To compare three different treatments in olive orchards and vegetable croplands, a representative study area in Polaca (Dalmatia, Croatia) was selected (WGS coordinates: $44^{\circ} 00^{\prime} \mathrm{N}$; $15^{\circ} 29^{\prime} \mathrm{E}$ ) at $71 \mathrm{~m}$ a.s.l. (Figure 1). The climate is Mediterranean with an average annual rainfall of $838 \mathrm{~mm}$ and an average annual temperature of $15.2^{\circ} \mathrm{C}$ (Vrana meteorological station $43^{\circ} 57^{\prime} \mathrm{N}, 15^{\circ} 28^{\prime} \mathrm{E}, 14 \mathrm{~m}$ a.s.1., $4.9 \mathrm{~km}$ from study area). The highest monthly rainfall occurs during September and October (109 and $102 \mathrm{~mm}$ ) and the lowest during July and August (28 and $52 \mathrm{~mm}$ ). The rainfall intensity of $60 \mathrm{~mm}$ per hour has a returning period of about 13 months (Zaninovic et al., 2008). The investigated area is a part of Ravni Kotari - lowland areas up to $200 \mathrm{~m}$ altitude, with the alternating limestone-dolomite hills and flysch valleys of the Dinaric lie (Fritz, 1978). Most of the Ravni Kotari area comprises water-permeable Cretaceous limestone and limestone breccia, and partially permeable dolomites and marl limestone. A small part is composed of watertight clastite (Fritz, 1978).

The soils in this area are classified as Calcaric Leptosol (IUSS-WRB, 2015). It is characterized by a clay-soil texture with $\sim 35 \%$ sand, $\sim 22 \%$ silt, and $\sim 43 \%$ clay, with rock fragments cover $<3 \%$. Some general properties register $1.93 \%$ of $\mathrm{OM}, 35.9 \mathrm{mg} \mathrm{kg}{ }^{-1}$ available phosphorus $\left(\mathrm{P}_{2} \mathrm{O}_{5}\right)$, and $59.9 \mathrm{mg}$ $\mathrm{kg}^{-1}$ available potassium $\left(\mathrm{K}_{2} \mathrm{O}\right)$. The region has a long tradition of production of olive, vines, and vegetables.

\section{Field experiments and laboratory analyses}

Three types of land use management were studied: vegetable croplands (CROP), grass-covered olive orchard (OGC), and tilled olive orchard (OT). The fields extend to cover an area of

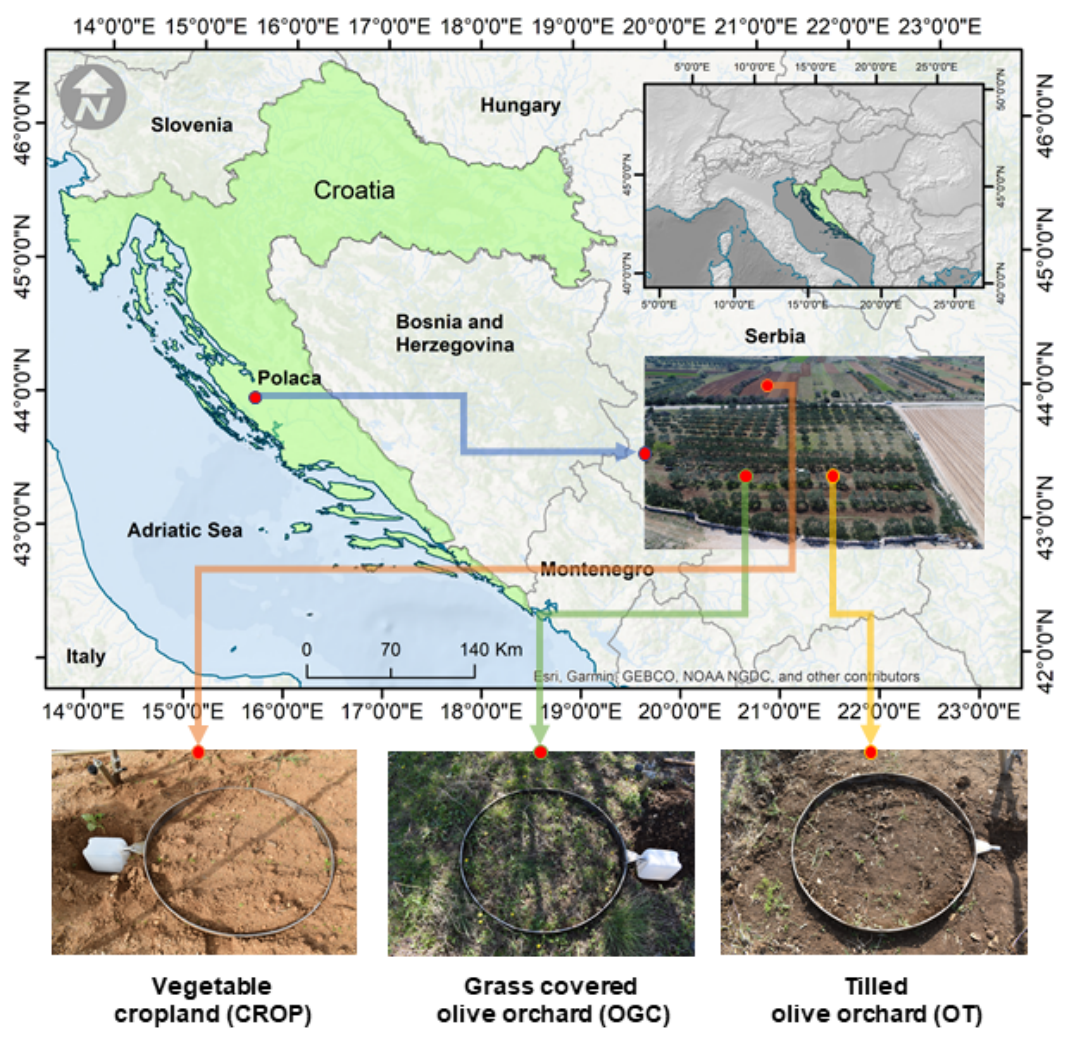

Fig. 1. Study area and plots of the selected rainfall simulation experimental plots. 
2.05 ha, all with medium-deep soil of similar properties. The vegetable cropland (CROP) was cultivated using the most common farming techniques in the region, which include moldboard plowing (up to $30 \mathrm{~cm}$ depth) in late autumn, followed by the rotation cultivator (up to $15 \mathrm{~cm}$ ). After each vegetable harvest, the soil is tilled by rotation cultivator before planting another culture. In CROP treatment, the usual number of cultures in the rotation was three per year. Fertilizer was applied to the treatment (before planting) in the form of 15-15$15 \mathrm{NPK}$ at a nominal rate of $800 \mathrm{~kg} \mathrm{ha}^{-1}$ and urea $150 \mathrm{~kg} \mathrm{ha}^{-1}$, rates typical of local cultivation practices. At the time of measurements, the spinach (Spinacia oleraceae L.) planted 15 days before covering a small portion of soil ( $<5 \%$ soil area). At the time of measurement, the CROP and OT treatment were tilled 15 and 60 days ago, respectively. Olives were managed with grass cover (OGC) between the trees. The grass is mowed and kept on the surface as a mulch. No herbicides were used here to suppress the weeds. Every several years the inter-row and row positions were fertilized using the 15-15-15 NPK in autumn at the nominal rate of $1000 \mathrm{~kg} \mathrm{ha}^{-1}$ and calcium ammonium nitrate $200 \mathrm{~kg} \mathrm{ha}^{-1}$ (in late spring during the flowering stage). The OT is conventionally tilled in each inter-row position by disking to a depth of $10 \mathrm{~cm}$. During the season, these tillage operations were repeated 3-4 times to keep the soil bare. During the field campaign, vegetation cover reached an average of about $11 \%$.

At CROP, OGC, and OT treatments, eight sampling points (separated by six meters) following a transect were selected to conduct the rainfall simulation experiments and soil sampling. Rainfall simulation experiments were performed during April 2019 under wet soil conditions (>20\% soil water content) with a rainfall simulator (UGT Rainmaker, Müncheberg, Germany). The device was calibrated to reproduce rainstorms of 58 $\mathrm{mm} \mathrm{h}^{-1}$ rainfall intensity, during 30 minutes on a circular plot of $0.785 \mathrm{~m}^{2}$ (metal ring $100 \mathrm{~cm}$ in diameter). Rainfall intensity was adjusted by the time that the nozzle (VeeJet $80 / 100$ nozzle, the pressure at $0.5 \mathrm{bar}$, at the height of $200 \mathrm{~cm}$ ) remains at the reversal points and nozzle turning speed (Schindewolf and Schmidt, 2012). Plastic collectors $(n=144)$ were placed under the rainfall simulator to collect the drops. After 30 minutes of the experiment at an intensity of $58 \mathrm{~mm} \mathrm{~h}^{-1}$, the rainfall distribution coefficient of variation is 4.66 . The mean drop size was $0.7 \mathrm{~mm}$, and the mean falling velocity was $6.263 \mathrm{~m} \mathrm{~s}^{-1}$.

After establishing each ring plot, undisturbed soil samples and soil core samples were taken from $10 \mathrm{~cm}$ downslope of each metal ring. Before the simulation, each plot was photographed to obtain vegetation cover (VC) percentage. To estimate the final VC, we used ArcGIS 10.2 software (ESRI, USA) to compare the relation on pixels to the vegetation in addition to the plot area. The slope was measured inside the ring area using a Bosch GLM 80 Professional instrument. Finally, when each simulation started, time to ponding (TP) and time to runoff generation (TR) were measured with a digital chronometer (Keesstra et al., 2019).

Undisturbed samples ( 8 per treatment, 24 in total) were collected at the $0-10 \mathrm{~cm}$ soil depth using $100 \mathrm{~cm}^{3}$ cylinders. The soil cores were wetted for determination of water holding capacity (WHC) and dried in an oven at $105^{\circ} \mathrm{C}$ for $24 \mathrm{~h}$ to obtain the bulk density (BD) according to Black (1965). Undisturbed samples ( 8 per treatment, 24 in total) were collected at the $0-10 \mathrm{~cm}$ depth, stored into rectangular boxes, and used for determination of the mean weight diameter (MWD) and the water-stable aggregates (WSA). During the procedure, the bulk soil was very carefully broken into small pieces by hands (Diaz-Zorita et al., 2002). After drying, the distribution of par- ticular aggregate size fractions $(<0.25,0.25-0.5,0.5-1.0$, $1.0-2.0,2.0-4.0,0.4-0.5$, and $0.5-0.8 \mathrm{~mm}$ ) was determined by dry sieving for 30 seconds (Kemper and Rosenau, 1986). MWD was calculated after weighting each aggregate size using the following equation (Eq. (1)):

$\mathrm{MWD}=\sum_{i=1}^{n} x i \cdot w i$,

where $x i$ is the mean diameter of any particular size range of aggregates separated by sieving, and $w i$ is the weight of aggregates in that size range as a fraction of the total dry weight of soil used. WSA was determined by wet sieving apparatus (similar to Kemper and Rosenau, 1986) by soaking $4 \mathrm{~g}$ of aggregates (diameter $0.4-0.5 \mathrm{~mm}$ ) in distilled water for $3 \mathrm{~min}$. After replacing cans with a dispersing solution $\left(2 \mathrm{~g} \mathrm{~L}^{-1}\right.$ sodium hydroxide), sieving continued until only the sand particles were left on the sieves. Both sets of cans were dried at $105^{\circ} \mathrm{C}$ and weighted. Percentage of WSA was obtained using the equation:

$\mathrm{WSA}=\frac{W d s}{W d s+W d w}$,

where WSA is the percentage of water-stable aggregates, $W d s$ is the weight of aggregates dispersed in dispersing solution (g), and $W d w$ is the weight of aggregate dispersed in distilled water (g). Remains of the aggregate sizes were milled and sieved through a $2 \mathrm{~mm}$ mesh to determine soil chemical properties. OM content was calculated according to the digestion method (Walkly and Black, 1934). Also, $\mathrm{P}_{2} \mathrm{O}_{5}$ concentration in soils and sediments (P loss) was determined after the samples were subjected to extraction with AL method (Egner et al., 1960) and using a spectrophotometer (Hach, Germany, model DR/2000). Finally, total nitrogen (TN) concentration in soils, as well as the carbon (C loss) and nitrogen ( $\mathrm{N}$ loss) concentrations in sediments, were obtained by a dry-combustion method using Vario MACRO CHNS analyzer.

During each rainfall simulation, the water and soil loss in the form of overland flow and suspended sediment was stored in a plastic container and then transported to the laboratory. The collected surface flow was weighed and filtered to obtain Run and soil loss (SL) after drying a filter paper. Sediment concentration (SC) was calculated, dividing the mass of SL by the mass of the Run in the samples. Dried sediments were milled and passed through $2 \mathrm{~mm}$ mesh as a preparation to analyze the $\mathrm{C}, \mathrm{N}$, and $\mathrm{P}_{2} \mathrm{O}_{5}$ as it was above-mentioned.

\section{Statistical analysis}

Before performing a statistical comparison of each result obtained for every treatment, data were checked for normality and heteroscedasticity using the Kolmogorov-Smirnov and Levene's tests. Data normality and homogeneity of the variances were considered at $p>0.05$. The majority of the variables showed a normal distribution. $\mathrm{VC}, \mathrm{C}$ loss, and $\mathrm{P}_{2} \mathrm{O}_{5}$ showed normality after a logarithmic transformation. A one-way ANOVA was used to identify significant differences among plots (VC, C loss and $\mathrm{P}_{2} \mathrm{O}_{5}$ with logarithmic transformation). If significant differences were found (at $p<0.05$ ), the Tukey HSD post-hoc test was applied. Data presented in the graphs were untransformed. A Principal Component Analysis (PCA) based on the correlation matrix was applied (using the log-transformed data) to identify association among the variables. Statistical analyses were carried out using Statistica 12.0 for windows. Graphics were depicted using Plotly (https://chart-studio.plot.ly). 


\section{RESULTS}

Environmental plot conditions and soil properties

Slope, VC, and soil properties for the different treatments are summarized in Table 1. Our results showed that there were no significant differences in slope among the treatments. VC in CROP (4.5\%) and OT (10.9\%) was significantly lower than VC in OGC $(83.6 \%)$. WSA and BD were also significantly different among all treatments. WHC values in CROP (37.3\%) were significantly lower than OGC (40.8\%). A similar situation was observed in BD. BD was as follows: CROP $\left(1.30 \mathrm{~g} \mathrm{~cm}^{-3}\right)<$ OGC $\left(1.32 \mathrm{~g} \mathrm{~cm}^{-3}\right)<$ OT $\left(1.42 \mathrm{~g} \mathrm{~cm}^{-3}\right)$. Also, no significant differences were identified in SWC which varied from $22.5 \%$ in the OT to $24.5 \%$ in the CROP treatment. MWD and WSA values ranged from $2.74 \mathrm{~mm}$ (CROP) to $3.72 \mathrm{~mm}(\mathrm{OGC})$ and from $46.7 \%$ (CROP) to $65.8 \%$ (OGC), respectively. Both parameters were significantly higher in OGC than to OT and CROP treatments. OM and TN were significantly different among treatments as follows: OGC $(2.53 \% \mathrm{OM} ; 0.14 \% \mathrm{TN})>$ OT $(1.88 \%$ OM; $0.10 \%$ TN $)>$ CROP $(0.86 \%$ OM; $0.05 \%$ TN $)$. Soil $\mathrm{P}_{2} \mathrm{O}_{5}$ ranged from 11.11 at OT to $92.08 \mathrm{mg} \mathrm{kg}^{-1}$ in the CROP treatment. $\mathrm{P}_{2} \mathrm{O}_{5}$ values were also significantly different among the treatments: CROP > OGC > OT.

\section{Initial soil erosion processes using rainfall simulation experiments}

The effects of soil management on hydrological response are shown in Figures 2 and 3. The TP ranged from 90 to $180 \mathrm{~s}$ (mean $123.7 \mathrm{~s}$ ) in the CROP plots, from 240 to $480 \mathrm{~s}$ (mean $307.5 \mathrm{~s}$ ) in the OT plots and from 300 to $540 \mathrm{~s}$ (mean $412.5 \mathrm{sec}$ ) in the OGC plots. The TR ranged from 180 to $300 \mathrm{~s}$ (mean $225.6 \mathrm{~s}$ ) in the CROP plots, from 420 to $1020 \mathrm{~s}$ (mean 652.5 $\mathrm{sec}$ ) in the OT plots and from 660 to $1140 \mathrm{~s}$ (mean $840 \mathrm{~s}$ ) in the OGC plots. In both cases, the CROP TP and TR values were significantly lower than in other plots. The Run values ranged from 10.4 to $15.6 \mathrm{~L} \mathrm{~m}^{-2}$ (mean $12.3 \mathrm{~L} \mathrm{~m}^{-2}$ ) in the CROP plots, from 0.78 to $3.06 \mathrm{~L} \mathrm{~m}^{-2}$ (mean $1.85 \mathrm{~L} \mathrm{~m}^{-2}$ ) in the OT plots and from 0.02 to $0.69 \mathrm{~L} \mathrm{~m}^{-2}$ (mean $0.26 \mathrm{~g} \mathrm{~L}^{-2}$ ) in the OGC plots. The SL values ranged from 85.5 to $246.1 \mathrm{~g} \mathrm{~m}^{-2}$ (mean $143.1 \mathrm{~g} \mathrm{~m}^{-2}$ ) in the CROP plots, from 10.5 to $64.8 \mathrm{~g} \mathrm{~m}^{-2}$ (mean $31.5 \mathrm{~g} \mathrm{~m}^{-2}$ ) in the OT plots and from 0.06 to $4.5 \mathrm{~g} \mathrm{~m}^{-2}$ (mean $1.8 \mathrm{~g} \mathrm{~m}^{-2}$ ) in the OGC plots. Significant differences were observed in the Run and SL among all treatments. On average, Run and SL were significantly higher in CROP than in OT and OGC. SC values ranged from $9.23 \mathrm{~g} \mathrm{~L}^{-1}$ to $30.05 \mathrm{~g} \mathrm{~L}^{-1}$ at OT plots, from $7.97 \mathrm{~g} \mathrm{~L}^{-1}$ to $15.81 \mathrm{~g} \mathrm{~L}^{-1}$ at CROP plots and from $3.31 \mathrm{~g} \mathrm{~L}^{-1}$ to $8.19 \mathrm{~g} \mathrm{~L}^{-1}$ at OGC plots. SC showed different behavior, exhibiting significantly high differences in OT plots (17.08 $\left.\mathrm{g} \mathrm{L}^{-1}\right)$, followed by the CROP plots $\left(11.30 \mathrm{~g} \mathrm{~L}^{-1}\right)$, and OGC plots $\left(6.16 \mathrm{~g} \mathrm{~L}^{-1}\right)$. The $\mathrm{P}$ loss, $\mathrm{N}$ loss, and $\mathrm{C}$ loss values at CROP, OT, and OGC plots ranged from $0.0003 \mathrm{~g} \mathrm{~m}^{-2}$ (OGC) to $0.1574 \mathrm{~g} \mathrm{~m}^{-2}$ (CROP), from $0.003 \mathrm{~g} \mathrm{~m}^{-2}$ (OGC) to $0.204 \mathrm{~g} \mathrm{~m}^{-2}$ (CROP) and from $0.07 \mathrm{~g} \mathrm{ha}^{-1}$ (OGC) to $9.87 \mathrm{~g} \mathrm{~m}^{-2}$ (CROP), respectively. $\mathrm{P}, \mathrm{N}$, and $\mathrm{C}$ loss were significantly higher at CROP plots than in OT and OGC plots.

\section{Principal component analysis}

The first three factors explained $77.1 \%$ of the total variance. Factor 1 explained 58.6\%, and Factors 2 and 3 explained 11.2\% and $7.3 \%$, respectively, of all variances. Factor 1 had high positive loadings in $\mathrm{VC}, \mathrm{WHC}, \mathrm{MWD}, \mathrm{WSA}, \mathrm{OM}, \mathrm{TN}, \mathrm{TP}$, and $\mathrm{TR}$, and high negative for $\mathrm{P}_{2} \mathrm{O}_{5}$, Run, SL, C loss, $\mathrm{P}$ loss and $\mathrm{N}$ loss (Table 2). Factor 2 had high positive loadings for BD and high negative loadings for SWC. Finally, factor 3 had high positive loadings in slope and SC. The intersection between Factor 1 and Factor 2 shows that Run, SL, $\mathrm{P}_{2} \mathrm{O}_{5}, \mathrm{~N}$ loss, P loss, and $\mathrm{C}$ loss are inversely related to the majority of the other variables, especially to the slope, VC, TP, TR, OM and TN (Figure 4A). The land management practices had different impacts on soil properties and hydrological response for all treatments. The impact is notably different between the CROP and the other treatments. The variability is much higher in the CROP in addition to OGC and OT (Figure 4B).

\section{DISCUSSION}

The results revealed that different land management changed some soil properties whereby the soil was more compacted at OT than at OGC and CROP plots. This is in agreement with the observations of previous studies. Tilled plots showed higher compaction than to the grassed ones in Mediterranean olive orchards (Gucci et al., 2012; López-Vicente and Álvarez, 2018). High BD at OT can be attributed to soil consolidation and tractor traffic, while a lower BD at CROP treatment can be related to the type of the tillage performance 15 days before conducting the measurements. Moreover, the experiments were conducted in a period without any traffic impact in this treatment. WHC was significantly higher in the OGC than the CROP plot, which was attributed to the vegetation cover on OGC plots. VC can improve the hydraulic properties of soils after several years and enhance the existence of medium-size pores to retain more water (Çerçioğlu et al., 2019). Moreover, higher root density of cover crops increases porosity and OM, with a notable improvement in soil structure (Jarvis et al., 2017;

Table 1. Results of one-way ANOVA analysis considering soil properties and plot conditions. Different letters after mean values in the columns represent significant difference at $p<0.05$; ns, not significant at a $p<0.05$. Abbreviations: CROP, vegetable cropland; OGC, olive orchard grass-covered, OT, olive orchard tilled; VC, vegetation cover; BD, bulk density; WHC, water holding capacity; SWC, soil water content; MWD, mean weight diameter; WSA, water-stable aggregates; OM, organic matter; $\mathrm{P}_{2} \mathrm{O}_{5}$, available phosphorous and TN, total nitrogen.

\begin{tabular}{|c|c|c|c|c|c|c|c|c|c|c|}
\hline Land use & Slope $\left(^{\circ}\right)$ & $\mathrm{VC}(\%)$ & WHC (\%) & SWC (\%) & $\begin{array}{c}\mathrm{BD} \\
\left(\mathrm{g} \mathrm{cm}^{-3}\right)\end{array}$ & MWD (mm) & WSA (\%) & $\mathrm{OM}(\%)$ & $\begin{array}{c}\mathrm{P}_{2} \mathrm{O}_{5} \\
\left(\mathrm{mg} \mathrm{kg}^{-1}\right)\end{array}$ & $\mathrm{TN}(\%)$ \\
\hline \multirow{2}{*}{ CROP } & 6.5 & 4.5 & \multirow{2}{*}{$37.3 \mathrm{~b}$} & \multirow{2}{*}{$24.5 \mathrm{a}$} & 1.30 & 2.74 & \multirow{2}{*}{$46.7 \mathrm{~b}$} & 0.86 & 92.08 & 0.05 \\
\hline & $\mathrm{a}$ & $\mathrm{b}$ & & & $\mathrm{b}$ & $\mathrm{b}$ & & $\mathrm{c}$ & $\mathrm{a}$ & $\mathrm{c}$ \\
\hline \multirow{2}{*}{ OGC } & 8.5 & 83.6 & \multirow{2}{*}{$40.8 \mathrm{a}$} & \multirow{2}{*}{$23.5 \mathrm{a}$} & 1.32 & 3.72 & \multirow{2}{*}{$65.8 \mathrm{a}$} & 2.53 & 20.49 & 0.14 \\
\hline & $\mathrm{a}$ & $\mathrm{a}$ & & & $a b$ & $\mathrm{a}$ & & $\mathrm{a}$ & $\mathrm{b}$ & $\mathrm{a}$ \\
\hline \multirow{2}{*}{ OT } & 7.9 & 10.9 & \multirow{2}{*}{$38.3 \mathrm{ab}$} & \multirow{2}{*}{$22.5 \mathrm{a}$} & 1.42 & 2.98 & \multirow{2}{*}{$48.4 \mathrm{~b}$} & 1.88 & 11.11 & 0.10 \\
\hline & $\mathrm{a}$ & $\mathrm{b}$ & & & $\mathrm{a}$ & $\mathrm{b}$ & & $\mathrm{b}$ & c & $\mathrm{b}$ \\
\hline$P$ value & n.s. & $* * *$ & $* *$ & n.s. & $*$ & $* * *$ & $* *$ & $* * *$ & $* * *$ & $* * *$ \\
\hline
\end{tabular}

*** Statistical significance at $p<0.001$. ** Statistical significance at $p<0.01$. $*$ Statistical significance at $p<0.05$. 

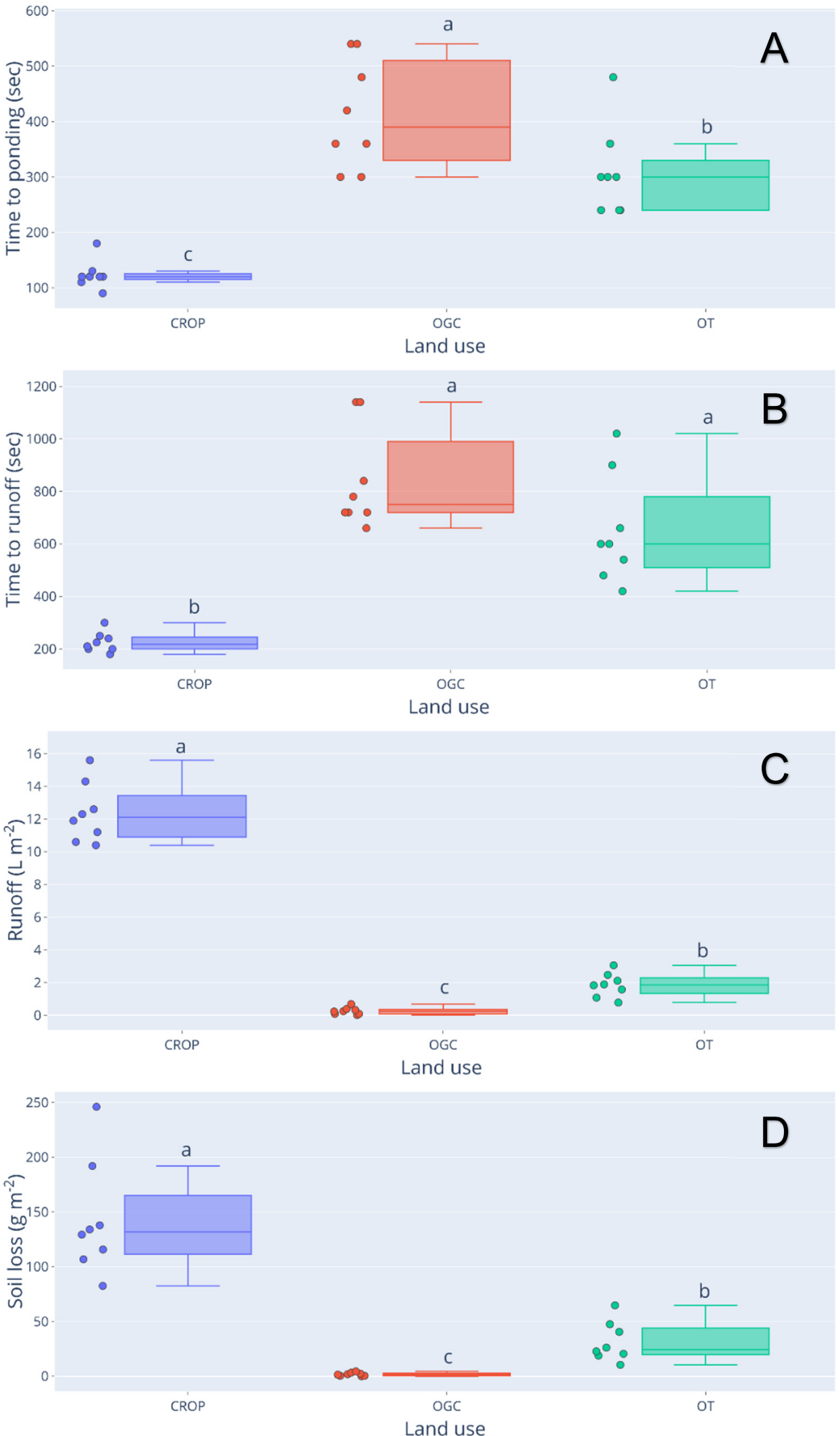

Fig. 2. Box plots and results of one-way ANOVA analysis for the effects of land use on A) time to ponding, B) time to runoff generation, C) runoff, and D) soil loss. Different letters represent a significant difference at $p<0.05$. Abbreviations: CROP, vegetable cropland, OGC, grass-covered olive orchard, OT, olive orchard tilled.

Zaibon et al., 2016). Our study also confirmed this behavior. Frequent tillage at OGC and OT plots expose soil aggregates to wet-dry cycles and disruptive raindrop impact, enhancing aggregates to disruption (Six et al., 2000). Tilled soil from subsoil was exposed to air, increasing the OM mineralization and decreasing their content compared to OGC. However, rotation type tillage performed several times a year at CROP plots created smaller aggregates and more considerable disturbance in addition to disking (Birkas et al., 2014) at the OT plot. It could be a reason for low OM occurring with this land use. 

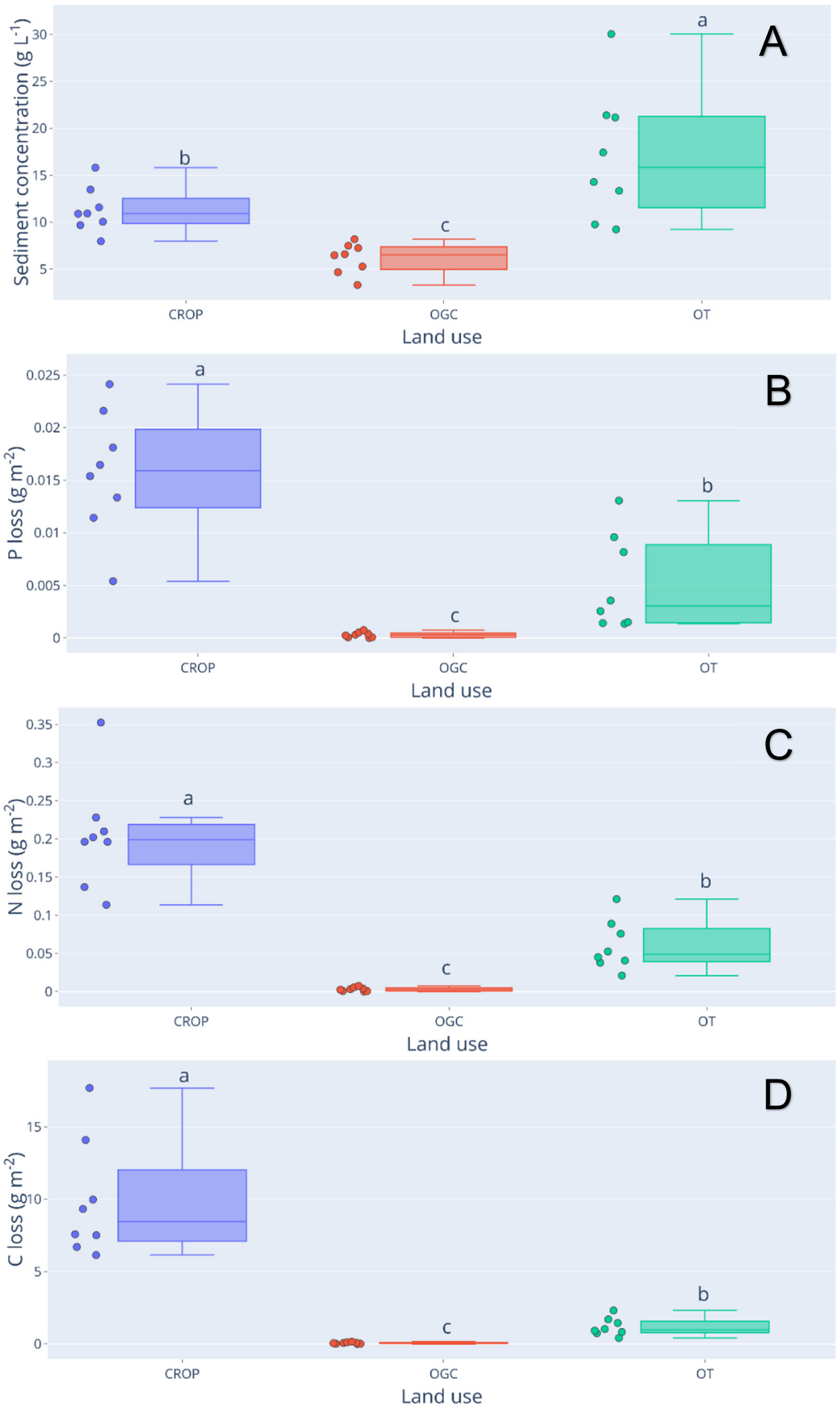

Fig. 3. Box plots and results of one-way ANOVA analysis for the effects of land use on A) sediment concentration, B) phosphorus loss (P loss), C) nitrogen loss (N loss), and D) carbon loss (C loss). Different letters represent a significant difference at $p<0.05$. Abbreviations: CROP, vegetable cropland, OGC, olive orchard grass-covered, OT, olive orchard tilled.

MWD and WSA were significantly higher at the OGC, compared to the OT and CROP treatment. Usually, aggregate stability is higher in grass-covered or no-tilled soils than the tilled ones (e.g., Blavet et al., 2009; Kay, 2018). This is attributed to the low OM concentration at CROP and OT plots, which cause soil structure degradation. Moreover, high MWD at the OGC plots formed a higher percentage of macro and medium-size pores. The lowest MWD at CROP plots enhanced higher micro-pores percentage in the soil. Such structure behavior directly affects WHC since it is known that soil water retention characteristic is highly related to the soil structure (Rabot et al., 2018). Significantly high $\mathrm{P}_{2} \mathrm{O}_{5}$ at $\mathrm{CROP}$ plots could be attributed to the intensive 

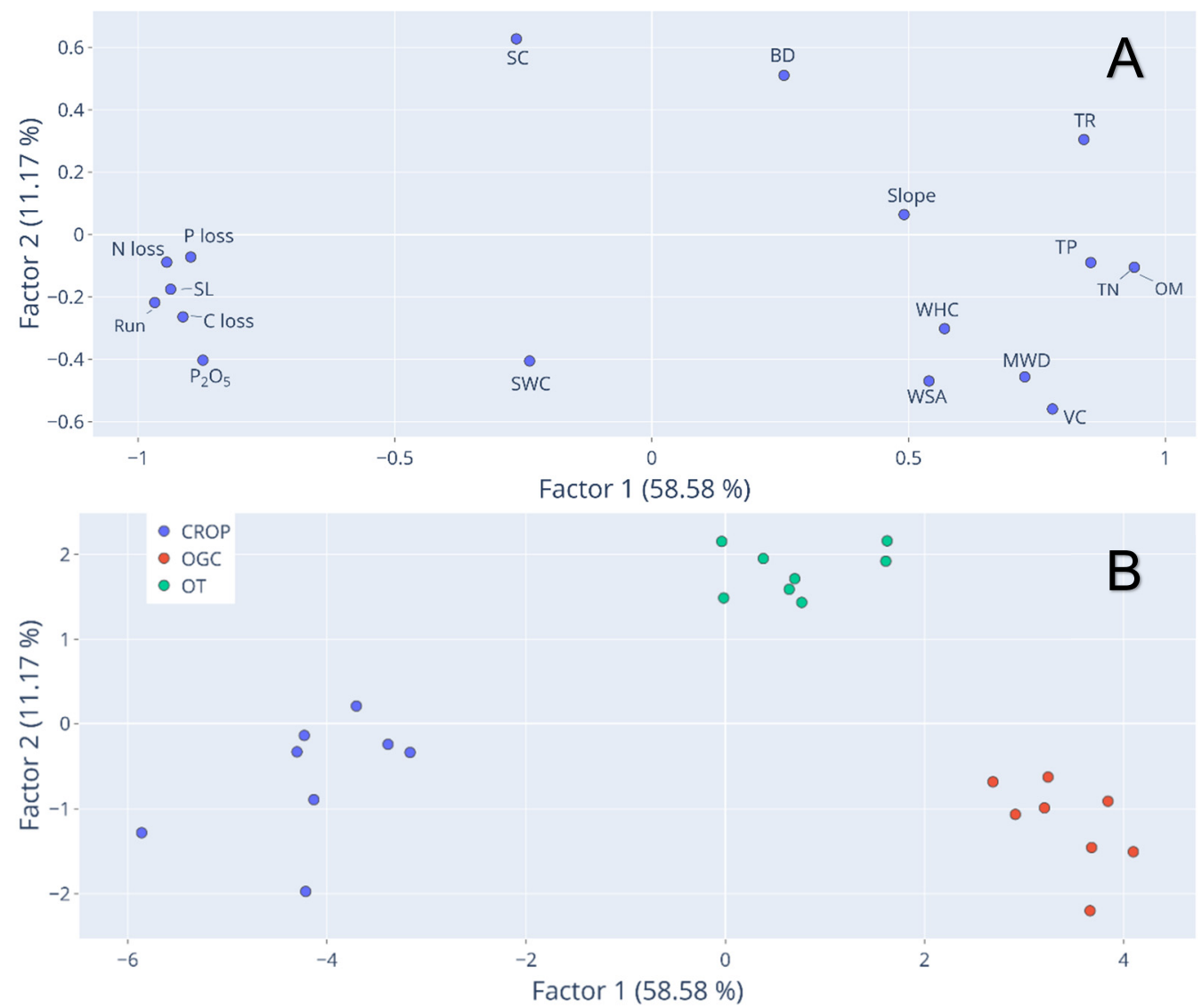

Fig. 4. Interaction among Factors 1 and 2, (A) Variables and (B) Cases considering different land-use management. Abbreviations: CROP, vegetable cropland; OGC, olive orchard grass-covered, OT, olive orchard tilled; VC, vegetation cover; BD, bulk density; WHC, water holding capacity; SWC, soil water content; MWD, mean weight diameter; WSA, water-stable aggregates; OM, organic matter; $\mathrm{P}_{2} \mathrm{O}_{5}$, available phosphorous; TN, total nitrogen; TP, time to ponding; TR, time to runoff; Run, runoff, SC, sediment concentration; SL, soil loss; N loss, nitrogen loss, C loss; carbon loss and P loss; phosphorus loss.

Table 2. Loadings matrix considering the first three factors extracted from the Principal Component Analysis. Eigenvalues retained in each factor are in bold. VC, Vegetation cover; BD, bulk density; WHC, water holding capacity; SWC, soil water content; MWD, mean weight diameter; WSA, water-stable aggregates; OM, organic matter; $\mathrm{P}_{2} \mathrm{O}_{5}$, available phosphorous; $\mathrm{TN}$, Total nitrogen; $\mathrm{TP}$, time to ponding; TR, time to runoff; Run, runoff; SC, sediment concentration; SL, soil loss; $\mathrm{N}$ loss, nitrogen loss; C loss, carbon loss and $\mathrm{P}$ loss, phosphorous loss.

\begin{tabular}{llll}
\hline Variable & Factor 1 & Factor 2 & Factor 3 \\
\hline Slope & 0.47492 & 0.092375 & $\mathbf{0 . 7 2 0 6 7 2}$ \\
VC & $\mathbf{0 . 7 9 1 9 7}$ & -0.537184 & 0.040386 \\
WHC & $\mathbf{0 . 5 8 0 8 5}$ & -0.290380 & 0.029580 \\
SWC & -0.23316 & $\mathbf{- 0 . 4 3 3 2 4 3}$ & 0.294177 \\
$\mathrm{BD}$ & 0.24896 & $\mathbf{0 . 4 8 7 3 1 4}$ & -0.303622 \\
$\mathrm{MWD}$ & $\mathbf{0 . 7 3 0 0 1}$ & -0.453207 & 0.053658 \\
$\mathrm{WSA}$ & $\mathbf{0 . 5 4 8 4 8}$ & -0.466899 & 0.090782 \\
$\mathrm{OM}$ & $\mathbf{0 . 9 3 9 2 9}$ & -0.078403 & 0.185447 \\
$\mathrm{P}_{2} \mathrm{O}_{5}$ & $\mathbf{- . 8 6 2 5 0}$ & -0.417675 & -0.063128 \\
$\mathrm{TN}$ & $\mathbf{0 . 9 3 9 2 9}$ & -0.078403 & 0.185447 \\
$\mathrm{TP}$ & $\mathbf{0 . 8 6 0 2 5}$ & -0.083010 & 0.045993 \\
$\mathrm{TR}$ & $\mathbf{0 . 8 6 5 5 9}$ & 0.033234 & -0.276317 \\
$\mathrm{Run}$ & $\mathbf{- 0 . 9 6 0 1 4}$ & -0.243496 & -0.059710 \\
$\mathrm{SL}$ & $\mathbf{- 0 . 9 3 3 8 4}$ & -0.213232 & 0.085730 \\
$\mathrm{SC}$ & -0.29574 & 0.602604 & $\mathbf{0 . 6 2 1 0 5 9}$ \\
$\mathrm{P}$ loss & $\mathbf{- 0 . 9 0 1 4 3}$ & -0.109361 & 0.229045 \\
$\mathrm{~N}$ loss & $\mathbf{- 0 . 9 4 3 6 0}$ & -0.124460 & 0.096008 \\
$\mathrm{C}$ loss & $\mathbf{- 0 . 9 0 6 8 1}$ & -0.301916 & 0.039662 \\
\hline
\end{tabular}

fertilization performed for each of several cultures per year on this treatment. However, TN concentrations in treatments are highly related to OM since it is a dominant source. Meanwhile, mineral $\mathrm{N}$ is known as susceptible to leaching, denitrification, and runoff (Robertson, 1997).

This study demonstrates that the use of frequent tillage for different land uses increases Run and erosion rates. We have to consider the small plot size used for the rainfall simulation experiments, which allow detecting the initial soil erosion activation and soil responses, therefore more research must be conducted using more repetitions or erosion plots for larger scales (Iserloh et al., 2013). Differences in soil loss between treatments occur due to following: CROP plots registered the lowest OM content, WSA and MWD, and VC, which contributes to a higher Run and SL when compared to OT. This is a consequence of intense tillage practices. Although all these variables were the lowest in CROP plot, which contributed to high overland flow and erosion rates, the highest BD was observed in OT. This was attributed to the fact that soil in CROP plots were more frequently tilled, decreasing OM and the stability of the aggregates. In addition, in crop plots soils were tilled with a rotation cultivator that is very destructive to soil aggregates (Birkas et al., 2014). This increases the vulnerability to sediment detachment. Our study agrees with others, e.g., in Spain, where tillage seems to be responsible for 3.6 times higher erosion rates and cover crop plots (Gómez et al., 2009). In clay-sandy soil in Italy, Fleskens and Stroosnijder (2007) reported $357 \%$ higher erosion rates on tilled olive orchard plots in addition to grass-covered plots. Vegetation protects the splash 
and delay Run due to stabile macropores, which enhance the infiltration (de Almeida et al., 2018; Çerçioğlu et al., 2019).

Moreover, grass cover act as a natural barrier for overland flow minimizes the sediment movement, and decreases the SC. Nutrient losses were significantly high in CROP and OT and follow a similar pattern as soil loss. The 52, 68, and 146 times higher losses of phosphorus, nitrogen, and carbon at CROP plots, in addition to OGC plots indicate the unsustainability of frequently tilled management. Also, a similar degradation dynamic is visible at OT plots with 17, 20, and 17 times higher phosphorus, nitrogen, and carbon loss in addition to OGC. Similar results were noted elsewhere (Bogunovic et al., 2020; Gómez et al., 2011).

PCA analysis supports the above-described results. Factor 1 revealed that the $\mathrm{VC}, \mathrm{WHC}, \mathrm{MWD}$, WSA, OM, TN, TP, and TR are positively associated. This is in agreement with other findings identified in the literature since high $\mathrm{VC}$ increases the rooting system, which secretes cementing agents and acts as an attractant for soil fauna as a source of food. This increases a high MWD and WSA, by secretion products as cementing agents for soil structure (Bogunovic et al., 2019b; Kay, 2018). Parallel with TP and TR, a high VC increases OM, which is beneficial to soil structure (Franzluebbers, 2002; Keesstra et al., 2019). Subsequently, it enhances the capacity of soils to retain water. The mentioned soil properties are inversely related to Run, SL, and C, N, and P loss. This dynamic was observed at CROP and OT plots (Figures 2 and 3) and confirms the idea that tillage practices trigger soil erosion and nutrient losses. Poor soil structure exacerbates soil hydrological response. Factor 2 inversely relates BD and SWC, while factor 3 relates slope and SC. High BD decreases and modifies the pore system and decreases the medium-sized pores, which retain soil water. The high SC in soils with high slope may be attributed to the higher overland flow energy, which detaches soil particles and increases their concentration in the Run. Overall, the type of soil management is a crucial factor in controlling erosion.

Our results also showed that specific land use management can influence soil ecosystems and, consequently, affect essential soil functions (Blavet et al., 2009; Mohammad and Adam, 2010; Qiang et al., 2016). In agricultural areas, soil erosion depends on natural soil properties, tillage methods, herbicides application, vegetation cover, and organic matter properties. Agricultural soils in Croatia are often bare soils because of the intense tillage or use of herbicides (Bogunovic et al., 2020). Thus, non-planned soil management considering these variations will enhance soil erosion rates. We claim the need for the adoption of more environmental and conservative soil erosion control measures. This current study demonstrates that tilled land uses (CROP and OT) have deteriorated structure, lower soil cover, and less resistance to sediment detachment and soil loss. Those findings demonstrate that conservation management and strategies for bare soils in olive orchards and vegetable croplands in Dalmatia need to be developed. The plantation of grass on the olive orchard or the reduction of tillage frequency on cropland vegetables could be a solution to increase VC. Also, there are important differences between OT and CROP, especially in soil structure, OM, and hydrological response. This shows that land-use management plays a crucial role in land sustainability. The high degradation among two tillage managements in different land uses very likely reflect the longterm impact of tillage intensity and vegetable cropland frequency. The current research contributes to a better understanding of the land-use management conducted in traditional agricultural sectors in Dalmatia. However, this is a first approach which uses rainfall simulation, obviously having serious limitation for an extrapolation for the whole cultivated area. Future research should be focused on the temporal variability and identification of runoff and erosion at different scales of catchments, considering the identification of critical geomorphological, pedological, and soil management practices.

\section{CONCLUSION}

Land use management substantially affected soil properties and soil hydrological response after simulated high-intensity rains. Tillage practices conducted in the Mediterranean decreased OM and soil structural quality, while grass coverage increased soil quality. In the vegetable cropland, soil WHC, MWD, WSA, OM, and TN were lower than in the grass-covered olive orchard. On the other hand, tilled olive orchard recorded lower MWD, WSA, OM, and TN than the OGC. High soil and nutrient losses were recorded at vegetable cropland and tilled olive orchard. Such results indicate that the application of frequent intensive tillage interventions at vegetable cropland very likely intensified soil degradation, overland flow, and soil and nutrient losses. WSA and MWD were probably affected by tillageinduced deterioration and mineralization of $\mathrm{OM}$ in long-time management in the vegetable cropland and tilled olive orchard. Soil and water losses in tilled olive plantations and vegetable croplands compared to grass-covered land olives in Dalmatia are not sustainable when using traditional tillage management. However, in grass-covered olive plantations, runoff and SL are low, indicating that soil structural stability and soil cover are vital factors to increase land-use sustainability.

Acknowledgements. This work was supported by the Croatian Science Foundation through the project "Soil erosion and degradation in Croatia" (UIP-2017-05-7834) (SEDCRO). The authors are grateful for the support of Family farm Bobanović from Polača.

\section{REFERENCES}

Abidela Hussein, M., Muche, H., Schmitter, P., Nakawuka, P., Tilahun, S.A., Langan, S., Barron, J., Steenhuis, T.S., 2019. Deep tillage improves degraded soils in the (sub)humid Ethiopian Highlands. Land, 8, 11, 159.

Arhonditsis, G., Giourga, C., Loumou, A., 2000. Ecological patterns and comparative nutrient dynamics of natural and agricultural Mediterranean-type ecosystems. Environ. Manage., 26, 5, $527-537$.

Bagarello, V., Ferro, V., Pampalone, V., Porto, P., Todisco, F., Vergni, L., 2018. Predicting soil loss in central and south Italy with a single USLE-MM model. J. Soil. Sediment. 18, 12, 3365-3377.

Baiamonte, G., Minacapilli, M., Novara, A., Gristina, L., 2019. Time scale effects and interactions of rainfall erosivity and cover management factors on vineyard soil loss erosion in the semiarid area of Southern Sicily. Water, 11, 978.

Beaufoy, G., Pienkowski, M., 2000. The environmental impact of olive oil production in the European Union: Practical options for improving the environmental impact. European Forum on Nature Conservation and Pastoralism. Available at: https://ec.europa.eu/environment/agriculture/pdf/oliveoil.pdf

Biddoccu, M., Ferraris, S., Pitacco, A., Cavallo, E., 2017. Temporal variability of soil management effects on soil hydrological properties, runoff and erosion at the field scale in a hillslope vineyard, North-West Italy. Soil Till. Res., 165, 46-58.

Birkas, M., Jug, D., Kisic, I., 2014. Book of Soil Tillage. Szent Istvan University, Godollo, Hungary, 322 p.

Black, C.A., 1965. Method of Soil Analysis. Part 2. Chemical and 
Microbiological Properties. American Society of Agronomy, Inc., Madison, $1159 \mathrm{p}$.

Blavet, D., De Noni, G., Le Bissonnais, Y., Leonard, M., Maillo, L., Laurent, J.Y., Asseline, J., Leprun, J.C., Arshad, M.A., Roose, E., 2009. Effect of land use and management on the early stages of soil water erosion in French Mediterranean vineyards. Soil Till. Res., 106, 1, 124-136.

Bogunovic, I., Pereira, P., Kisic, I., Sajko, K., Sraka, M., 2018. Tillage management impacts on soil compaction, erosion and crop yield in Stagnosols (Croatia). Catena, 160, 376-384.

Bogunovic, I., Fernández, M.P., Kisic, I., Marimón, M.B., $2019 \mathrm{~b}$. Agriculture and grazing environments. In: Pereira, P. (Ed.): Soil Degradation, Restoration and Management in a Global Change Context. 1st ed. Elsevier, London, UK, Volume 4, pp. 23-70.

Bogunovic, I., Telak, L.J., Pereira, P., 2020. Agriculture management impacts on soil properties and hydrological response in Istria (Croatia). Agronomy, 10, 2, 282.

Çerçioğlu, M., Anderson, S.H., Udawatta, R. P., Alagele, S., 2019. Effect of cover crop management on soil hydraulic properties. Geoderma, 343, 247-253.

Covelli, C., Cimorelli, L., Pagliuca, D.N., Molino, B., Pianese, D., 2020. Assessment of erosion in river basins: A distributed model to estimate the sediment production over watersheds by a 3Dimensional LS Factor in RUSLE Model. Hydrology, 7, 1, 13.

Dalla Rosa, J., Cooper, M., Darboux, F., Medeiros, J.C., Campanaro, C., Martins Pinto, L.R., 2017. Influence of crust formation on soil porosity under tillage systems and simulated rainfall. Hydrology, 4, 1, 3.

de Almeida, W.S., Panachuki, E., de Oliveira, P.T.S., da Silva Menezes, R., Sobrinho, T.A., de Carvalho, D.F., 2018. Effect of soil tillage and vegetal cover on soil water infiltration. Soil Till. Res., 175, 130-138.

Diaz-Zorita, M., Perfect, E., Grove, J.H., 2002. Disruptive methods for assessing soil structure. Soil Till. Res., 64, 1-2, 3-22.

Dunjó, G., Pardini, G., Gispert, M., 2004. The role of land useland cover on runoff generation and sediment yield at a microplot scale, in a small Mediterranean catchment. J. Arid Environ., 57, 2, 239-256.

Ebabu, K., Tsunekawa, A., Haregeweyn, N., Adgo, E., Meshesha, D.T., Aklog, D., Masunaga, T., Tsubo, M., Sultan, D., Fenta, A.A., Yibeltal, M., 2020. Exploring the variability of soil properties as influenced by land use and management practices: A case study in the Upper Blue Nile basin, Ethiopia. Soil Till. Res., 200, 104614.

Ebert, A.W., Dubois, T., Tenkouano, A., Mavlyanova, R., Wang, J.F., HanumanthaRao, B., Ramasamy, S., Kumar, S., Beed, F.D., Pottorff, M., Chen, W.Y., Nair, R.M., Nayyar, H., Chen, W.Y., 2019. Sustainable vegetable production to sustain food security under climate change at global level (No. RESEARCH), In: Yadav, S.S., Redden, R.J., Hatfield, J.L., Ebert, A.W., Hunter, D. (Eds): Food Security and Climate Change. $1^{\text {st }}$ Edition. John Wiley \& Sons Ltd, pp. 319-358.

Egnér, H.A.N.S., Riehm, H., Domingo, W.R., 1960. Untersuchungen über die chemische Bodenanalyse als Grundlage für die Beurteilung des Nährsto zustandes der Böden. II. Chemische Extraktionsmethoden zur Phosphor-und Kaliumbestimmung. Lantbrukshögskolans Ann., 26, 199-215.

Espadas-Aldana, G., Vialle, C., Belaud, J.-P., Vaca-Garcia, C., Sablayrolles, C., 2019. Analysis and trends for Life Cycle Assessment of olive oil production. Sustainable Production and Consumption, 19, 216-230.

FAO, 2015. Healthy soils are the basis for healthy food production. Food and Agriculture Organization of the United Nations. Available at: http://www.fao.org/3/a-i4405e.pdf

Fleskens, L., Stroosnijder, L., 2007. Is soil erosion in olive groves as bad as often claimed? Geoderma, 141, 3-4, 260-271.

Franzluebbers, A.J., 2002. Water infiltration and soil structure related to organic matter and its stratification with depth. Soil Till. Res., 66, 197-205.
Fritz, F., 1978. Hydrogeology of Ravni Kotari and Bukovica. Carsus lugoslaviae 10/1, JAZU Zagreb, 43 p.

García-Ruiz, J.M., Beguería, S., Lana-Renault, N., Nadal-Romero, E., Cerdà, A., 2017. Ongoing and emerging questions in water erosion studies. Land Degrad. Dev., 28, 5-21.

Gilley, J.E., Doran, J.W., Karlen, D.L., Kaspar, T.C., 1997. Runoff, erosion, and soil quality characteristics of a former Conservation Reserve Program site. J. Soil Water Conserv. 52, 3, 189-193.

Gómez, J.A., Sobrinho, T.A., Giráldez, J.V., Fereres, E., 2009. Soil management effects on runoff, erosion and soil properties in an olive grove of Southern Spain. Soil Till. Res., 102, 1, 5-13.

Gómez, J.A., Giráldez, J.V., Vanwalleghem, T., 2008. Comments on "Is soil erosion in olive groves as bad as often claimed?" by L. Fleskens and L. Stroosnijder. Geoderma, 147, 93-95.

Gómez, J.A., Llewellyn, C., Basch, G., Sutton, P.B., Dyson, J.S., Jones, C.A., 2011. The effects of cover crops and conventional tillage on soil and runoff loss in vineyards and olive groves in several Mediterranean countries. Soil Use Manage., 27, 4, 502514.

Gómez, J.A., Campos, M., Guzmán, G., Castillo-Llanque, F., Vanwalleghem, T., Lora, Á., Giráldez, J.V., 2018. Soil erosion control, plant diversity, and arthropod communities under heterogeneous cover crops in an olive orchard. Environ. Sci. Pollut. Res., 25, 2, 977-989.

Gucci, R., Caruso, G., Bertolla, C., Urbani, S., Taticchi, A., Esposto, S., Servili, M., Sifola, M.I., Pellegrini, S., Pagliai, M., Vignozzi, N., 2012. Changes of soil properties and tree performance induced by soil management in a high-density olive orchard. Eur. J. Agron., 41, 18-27.

Iserloh, T., Ries, J. B., Arnáez, J., Boix-Fayos, C., Butzen, V., Cerdà, A., Echeverría, M.T., Fernández-Gálvez, J., Fister, W., Geißler, C., Gómez, J.A., Gómez-Macpherson, H., Kuhn, N.J., Lázaro, R., León, F.J., Martínez-Mena, M., Martínez-Murillo, J.F., Marzen, M., Mingorance, M.D., Ortigosa, L., Peters, P., Regüés, D., Ruiz-Sinoga, J.D., Scholten, T., Seegera, M., SoléBenet, A., Wengel, R., Wirtz, S., 2013. European small portable rainfall simulators: A comparison of rainfall characteristics. Catena, 110, 100-112.

IUSS-WRB, 2015. World Reference Base for Soil Resources 2014, Update 2015: International Soil Classification System for Naming Soils and Creating Legends for Soil Maps. World Soil Resources Reports No. 106; FAO, Rome, Italy, 192 p.

Jarvis, N., Forkman, J., Koestel, J., Kätterer, T., Larsbo, M., Taylor, A., 2017. Long-term effects of grass-clover leys on the structure of a silt loam soil in a cold climate. Agric. Ecosyst. Environ., 247, 319-328.

Kay, B.D., 2018. Soil structure and organic carbon: a review, in: Lal, R., Kimble, J.M., Follett, R.F., Stewart B.A. (Eds.): Soil Processes and the Carbon Cycle. 1st edition, CRC Press: Boca Raton, Florida USA, pp. 169-197.

Kemper, W.D., Rosenau, R.C., 1986. Aggregate stability and size distribution. In: Klute, A. (Ed.): Methods of Soil Analysis. American Society of Agronomy, Inc., Madison, pp. 425-442.

Keesstra, S.D., Rodrigo-Comino, J., Novara, A., Giménez-Morera, A., Pulido, M., Di Prima, S., Cerdà, A., 2019. Straw mulch as a sustainable solution to decrease runoff and erosion in glyphosate-treated clementine plantations in Eastern Spain. An assessment using rainfall simulation experiments. Catena, 174, 95-103.

Kosmas, C., Danalatos, N., Cammeraat, L.H., Chabart, M., Diamantopoulos, J., Farand, R., Gutierrez, L., Jacob, A., Marques, H., Martinez-Fernandez, J., Mizara, A., Moustakas, N., Nicolau, J.M. Oliveros, C., Pinna, G., Puddu, R., Puigdefabregas, J., Roxo, M., Simao, A., Stamou, G., Tomasi, N., Usai, D., Vacca, A., 1997. The effect of land use on runoff and soil erosion rates under Mediterranean conditions. Catena, 29, 1, 45-59.

Kosmas, C., Detsis, V., Karamesouti, M., Kounalaki, K., Vassiliou, P., Salvati, L., 2015. Exploring long-term impact of grazing 
management on land degradation in the socio-ecological system of Asteroussia Mountains, Greece. Land, 4, 3, 541-559.

López-Vicente, M., Álvarez, S., 2018. Stability and patterns of topsoil water content in rainfed vineyards, olive groves, and cereal fields under different soil and tillage conditions. Agric. Water Manage., 201, 167-176.

Ludwig, M., Wilmes, P., Schrader, S., 2018. Measuring soil sustainability via soil resilience. Sci. Total Environ., 626, 14841493.

Martínez, J.R.F., Zuazo, V.H.D., Raya, A.M., 2006. Environmental impact from mountainous olive orchards under different soilmanagement systems (SE Spain). Sci. Total Environ., 358, 1-3, $46-60$.

Mohammad, A.G., Adam, M.A., 2010. The impact of vegetative cover type on runoff and soil erosion under different land uses. Catena, 81, 2, 97-103.

Montgomery, D.R., 2007. Soil erosion and agricultural sustainability. Proc. Natl. Acad. Sci. U.S.A., 104, 33, 13268-13272.

Návar, J., Synnott, T.J., 2000. Surface runoff, soil erosion, and land use in Northeastern Mexico. Terra Latinoam., 18, 3, 247-253.

Novara, A., Favara, V., Novara, Amelia, Francesca, N., Santangelo, T., Columba, P., Chironi, S., Ingrassia, M., Gristina, L., 2020. Soil Carbon Budget Account for the Sustainability Improvement of a Mediterranean Vineyard Area. Agronomy, 10, 336.

O'Rourke, M.E., Petersen, J., 2016. Reduced tillage impacts on pumpkin yield, weed pressure, soil moisture, and soil erosion. HortScience, 51, 12, 1524-1528.

Pereira, P., Bogunovic, I., Muñoz-Rojas, M. Brevik, E.C., 2018 a. Soil ecosystem services, sustainability, valuation and management. Curr. Opin. Environ. Sci. Health, 5, 7-13.

Pereira, P., Francos, M., Brevik, E.C., Ubeda, X., Bogunovic, I., 2018b. Post-fire soil management. Curr. Opin. Environ. Sci. Health, 5, 26-32.

Plotly. Available online: https://chart-studio.plot.ly/ (accessed on 09 March 2020).

Pournader, M., Ahmadi, H., Feiznia, S., Karimi, H., Peirovan, H.R., 2018. Spatial prediction of soil erosion susceptibility: an evaluation of the maximum entropy model. Earth Sci. Inform., 11, 3, 389-401.

Preiti, G., Romeo, M., Bacchi, M., Monti, M., 2017. Soil loss measure from Mediterranean arable cropping systems: Effects of rotation and tillage system on C-factor. Soil Till. Res., 170, 85-93.

Qiang, F.E.N.G., Wenwu, Z.H.A.O., Jun, W.A.N.G., Zhang, X., Mingyue, Z.H.A.O., Zhong, L., Yuanxin, L.I.U., Xuening, F.A.N.G., 2016. Effects of different land-use types on soil erosion under natural rainfall in the Loess Plateau, China. Pedosphere, 26, 2, 243-256.

Rabot, E., Wiesmeier, M., Schlüter, S., Vogel, H.J., 2018. Soil structure as an indicator of soil functions: a review. Geoderma, $314,122-137$.
Ryken, N., Nest, T.V., Al-Barri, B., Blake, W., Taylor, A., Bodé, S., Ruysschaert, G., Boeckxd, P., Verdoodt, A., 2018. Soil erosion rates under different tillage practices in central Belgium: New perspectives from a combined approach of rainfall simulations and 7Be measurements. Soil Till. Res., 179, 29-37.

Robertson, G.P., 1997. Nitrogen use efficiency in row-crop agriculture: crop nitrogen use and soil nitrogen loss. In: Jackson, L.E. (Ed.): Ecology in Agriculture. Academic Press, San Diego, USA, pp. 347-365.

Salvia, R., Egidi, G., Vinci, S., Salvati, L., 2019. Desertification risk and rural development in Southern Europe: Permanent assessment and implications for sustainable land management and mitigation policies. Land, 8, 12, 191.

Sanaullah, M., Usman, M., Wakeel, A., Cheema, S.A., Ashraf, I., Farooq, M., 2020. Terrestrial ecosystem functioning affected by agricultural management systems: A review. Soil Till. Res., 196, 104464.

Schindewolf, M., Schmidt, J., 2012. Parameterization of the EROSION 2D/3D soil erosion model using a small-scale rainfall simulator and upstream runoff simulation. Catena, 91, 4755.

Six, J., Paustian, K., Elliott, E.T., Combrink, C., 2000. Soil structure and organic matter. I. Distribution of aggregate-size classes and aggregate-associated carbon. Soil Sci. Soc. Am. J., 64, 2, $681-689$.

Steffan, J.J., Brevik, E.C., Burgess, L.C., Cerdà, A., 2018. The effect of soil on human health: an overview. Eur. J. Soil Sci., $69,1,159-171$.

Taguas, E.V., Guzmán, E., Guzmán, G., Vanwalleghem, T., Gómez, J.A., 2015. Characteristics and importance of rill and gully erosion: a case study in a small catchment of a marginal olive grove. Cuad. de Investig. Geogr., 41, 107-126.

Triplett Jr, G. B., Dick, W.A., 2008. No-tillage crop production: A revolution in agriculture! Agronomy J., 100, S-153.

Vanwalleghem, T., Amate, J.I., de Molina, M.G., Fernández, D.S., Gómez, J.A., 2011. Quantifying the effect of historical soil management on soil erosion rates in Mediterranean olive orchards. Agric. Ecosyst. Environ., 142, 3-4, 341-351.

Walkly, A., Black, I.A., 1934. An examination of digestion methods for determining soil organic matter and a proposed modification of the chromic and titration. Soil Sci. Soc. Am. J., 37, 29-38.

Zaibon, S., Anderson, S.H., Kitchen, N.R., Haruna, S.I., 2016. Hydraulic properties affected by topsoil thickness in switchgrass and corn-soybean cropping systems. Soil Sci. Soc. Am. J., 80, 5, 1365-1376.

Zaninović, K., Gajić-Čapka, M., Perčec Tadić, M., Vučetić, M., Milković, J., Bajić, A., Cindrić, K., Cvitan, L., Katušin, Z., Kaučić, D., Likso, T., Lončar, E., Lončar, Z., Mihajlović, D., Pandžić, K., Patarčić, M., Srnec, L., Vučetić, V., 2000. Climate Atlas of Croatia: 1961-1990:1971-2000. Meteorological and Hydrological Service, Zagreb. 